\title{
ARAŞTIRMA / RESEARCH \\ Postmenapozal kadınlarda kas iskelet sistemi ağrılarının D vitamini eksikliği ile ilişkisi
}

\author{
Relationship between vitamin D deficiency and musculoskeletal pain in \\ postmenopausal women
}

Eda Çelik Güzel

Namık Kemal Üniversitesi Tip Fakültesi Aile Hekimliği Anabilim Dalı, Tekirdağ, Turkey

\begin{abstract}
Purpose: The aim of this study was to investigate the effect of vitamin D deficiency on the appearance of musculoskeletal pain seen in postmenopausal women.

Material and Methods: The study consisted of 130 patients in the postmenopausal period and 50 healthy volunteers. Patients and control group were assessed with demographic information and visual analogue scale (VAS) and pain scores. Serum 25-hydroxyvitamin D (25 (OH) D), estradiol (E2) calcium, phosphorus, alkaline phosphatase (ALP) and parathormone (PTH) levels were evaluated.
\end{abstract}

Results: The mean age of the subjects participating in the study was $51.03 \pm 4.22$ and the control group was $48.27 \pm 5.47$ years. Serum $25(\mathrm{OH}) \mathrm{D}$ level was significantly lower in the patient group than in the control group. There was no difference between the two groups in calcium, phosphorus, ALP and PTH levels. The VAS pain score used to assess pain status was significantly higher in the patient group than in the control group $(\mathrm{p}<0.001)$ VAS pain scores in Postmenopausal patients were significantly higher in patients with vitamin D deficiency and inadequate than those with adequate vitamin $\mathrm{D}$ levels. In patients group serum $25(\mathrm{OH}) \mathrm{D}$ were negatively correlated with age, body mass index and VAS score and positively correlated with exercise and E2.

Conclusion: The increase in pain intensity in postmenopausal patients is associated with a decrease in serum $25(\mathrm{OH})$ D levels. Moreover, we believe that 25 $(\mathrm{OH}) \mathrm{D}$ levels are more common in patients with lower levels of the lower extremities and that serum $25(\mathrm{OH}) \mathrm{D}$ may play a role in determining the severity of musculoskeletal pain.

Key words: Postmenopausal period, vitamin D musculoskeletal system pain.

\section{Öz}

Amaç: Bu çalışmanın amacı postmenapozal dönemdeki kadınlarlarda görülen kas iskelet sistemi ağrılarının ortaya çıkmasında D vitamini eksikliğinin etkisini araştırmaktır

Gereç ve Yöntem: Calıșma postmenapozal dönemde olan 130 hasta ve 50 sağllklı gönüllüden oluşturuldu. Hasta ve kontrol grubunda hastaların demografik bilgileri ve visual analog skala (VAS) ile ağrı skorları belirlendi. Serum 25 hidroksi D vitamini $(25(\mathrm{OH}) \mathrm{D})$, Östrodiol (E2), kalsiyum, fosfor, alkalen fosfataz (ALP) ve parathormon (PTH) düzeyleri değerlendirildi.

Bulgular: Çalışmaya katılan hastaların yaş ortalaması $51.03 \pm 4.22$ ve kontrol grubunun ise $48.37 \pm 5.47$ yild1. Serum $25(\mathrm{OH}) \mathrm{D}$ düzeyi hasta grubunda kontrol grubuna göre anlamlı olarak düşüktü. Kalsiyum, fosfor, ALP ve PTH düzeyleri arasında her iki grup arasında farklılık görülmedi. Ağrı durumunu değerlendirmek için kullanılan VAS ağr1 skoru hasta grubunda kontrol grubuna göre anlamlı olarak yüksek saptandi. Postmenapozal hastalarda VAS ağr1 skorları D vitamini eksikliği ve yetersizliği olan gruplarda, D vitamini düzeyleri yeterli olan gruba göre anlamlı olarak yüksek saptandi. Hasta grubunda uygulanan korelasyon analizinde $25(\mathrm{OH}) \mathrm{D}$ düzeyleri ile yaş, vücut kütle indeksi ve VAS skoru arasinda negatif korelasyon ve egzersiz ve E2 arasinda pozitif korelasyon saptandi.

Sonuç: Postmenapozal hastalarda ağrı şiddetindeki artışın serum $25(\mathrm{OH}) \quad \mathrm{D}$ düzeylerindeki azalmayla ilișkili olduğunu göstermektedir. Üstelik 25(OH)D düzeyleri düşük hastalarda alt ekstremite ağrilarının daha fazla görüldüğü veserum $25(\mathrm{OH})$ D'nin kas iskelet sistemi ağrılarının şiddetini belirlemede rol oynayabileceği kanısindayı.

, Anahtar kelimeler: Postmenapozal dönem, D vitamini, kas iskelet sistem ağris1.

Yazışma Adresi/Address for Correspondence: Dr. Eda Çelik Güzel, Namık Kemal Üniversitesi Tıp Fakültesi Aile Hekimliği Anabilim Dall; Tekirdağ, Turkey. E-mail: celikguzel@gmail.com

Geliş tarihi/Received: 01.12.2016 Kabul tarihi/Accepted: 10.01.2017 


\section{GİRİŞ}

Kas iskelet sistemi ağrıları (KİSA) milyonlarca insanı etkileyen önemli bir sağlık sorunudur. Fiziksel engelliğin en yaygın nedenidir. Uzun süreli ağr1, sıkıntı ve büyük sağlık maliyetlerine yol açmaktadır ${ }^{1,2}$. KİSA'na katkıda bulunabilecek hastalıkların ve durumların oldukça fazla olması göz önüne alındığında ayırıcı tanısı zordur. Bu nedenle, araştırmacıların etkili müdahale stratejileri geliştirmeleri için, altta yatan ağrı mekanizmalarının iyi analiz etmeleri gerekmektedir.

Kadınlarda postmenopozal dönemdeki fizyolojik değişikliklerin kas iskelet sistemi üzerine olan etkisi dikkat çekicidir. Bu dönemdeki kadınlarda gonadal hormonlardan özellikle östrojendeki değişiklikler kas iskelet sistemi üzerinde ciddi modifikasyonlara neden olur ${ }^{3,4,5}$. Östrojenin kaslar, tendonlar, ligamentler ve kemikler üzerinde önemli rolleri vardir ${ }^{5}$. Postmenopozal evrede KİSA'yı da içeren birçok şikayetin bu dönemde olduğu bilinmektedir ${ }^{6}$. $\mathrm{Bu}$ nedenle östrojen düşüklüğü, KİSA ile ilişkili anahtar faktör olabilir.

D vitamini eksikliği yaşlı erişkinlerde kırık riski ${ }^{7}$, alt ekstremite fonksiyonlarında bozukluk ${ }^{8}$, osteomalazi ve ağr1 ${ }^{9}, 10,11,12$ gibi durumlarla ilişkili bulunmuştur. D vitamininin kalsiyum homeostazındaki rolü kemik ve kas sağlı̆̆1 açısından kritik öneme sahiptir ${ }^{13}$. Ancak ağr1 sendromlarının gelişiminde D vitamininin rolü çok az bilinmektedir. Postmenopozal kadınlarda D vitamini yetersizliği ve eksikliği birçok ülkede yüksek sıklıkta tespit edilmiștir ${ }^{14}$. Düşük serum 25-hydroksiD vitamini $(25(\mathrm{OH}) \mathrm{D})$ konsantrasyonları kalsiyum emilimini azaltarak kemik kütlesinde azalmaya ve kemik ağrısının başlamasına yol açar ${ }^{15}$. Üstelik D vitamini eksikliği postural kas gücünün azalmasının ve sarkopeninin bilinen en önemli nedenidir ${ }^{13,16}$.

$\mathrm{Bu}$ çalışmada amacımız postmenapozal evredeki kadınlarda D vitamini düzeylerini sağlıklı kontrol grubu ile karşılaştırmak ve $25(\mathrm{OH}) \mathrm{D}$ düzeyleri ile KİSA arasındaki ilișkiyi araștırmaktır.

\section{GEREÇ VE YÖNTEM}

Bu çalışma, Ocak 2014-Mayıs 2016 tarihleri arasında Namık Kemal Üniversitesi Araştırma Uygulama Merkezi Aile Hekimliği Polikliniğine başvuran 180 gönüllü hasta üzerinde retrospektif olarak yapıldı. Çalışmaya Namık Kemal Üniversitesi Tıp Fakültesi Girișimsel Olmayan Klinik Araștırmalar Etik
Kurulu'nun 12.05.2016 tarih ve 2016/81/05/14 sayılı onayı alınarak başlandı. 40 yaşından sonra son 1 yildır adet görmeyen ve hormon replasman tedavisi kullanmayan doğal menopozdaki hastalar çalışmaya dahil edildi. Folikül stimülan hormon (FSH) değerleri sırasıyla $30 \mathrm{IU} / \mathrm{ml}$ üzerinde olan ve östradiol (E2) değerleri $20 \mathrm{pg} / \mathrm{ml}$ 'nin altında olan hastalara menopoz tanisı kondu. Hastaların ilk poliklinik başvuruları esnasında edinilmiş olan demografik bilgileri, ağr1 şikayetleri, Vizüel Analog Skala (VAS) ölçümleri ve serum kalsiyum, fosfor, alkalen fosfataz (ALP), parathormon (PTH) ve $25(\mathrm{OH}) \mathrm{D}$ düzeyleri kaydedildi. D vitamini düzeylerinin $\leq 20 \mathrm{ng} / \mathrm{ml}$ olması "D vitamini düşük", 21-29 $\mathrm{ng} / \mathrm{ml}$ arasındaki değerler " $\mathrm{D}$ vitamini yetersiz", $\geq 30 \mathrm{ng} / \mathrm{ml}$ olmas1 "D vitamini yeterli" olarak tanımland $1^{17}$. Hastalar D vitamini düzeylerine göre üç gruba ayrıldı. D vitamini düzeyleri yeterli bulunanlar Grup I'de, yetersizliği bulunanlar Grup II'de, düşük bulunan hastalar Grup III'te yer aldı.

\section{Laboratuvar testleri}

25(OH)D düzeyi, serum örneklerinde HPLC yöntemi ile ölçüldü. PTH, $\mathrm{E}_{2}$ ve $\mathrm{FSH}$ düzeyleri Elektrokemilüminesans Immünassay yöntemi kullanilarak, Roche Modular Analytics E170 Immunoassay analizöründe ölçüldü. Serum kalsiyum, fosfor, ALP, glukoz, total kolesterol, trigliserid, HDL kolesterol biyokimya otoanalizöründe standart metodlarla çalışıldı.

\section{Ağrının değerlendirilmesi}

Olguların ağrı değerlendirilmesi Vizüel Analog Skala (VAS) ile yapıldı. Bunun için $10 \mathrm{~cm}$ 'lik cetvel kullanıldı. Hastalara $10 \mathrm{~cm}$ 'lik bir çizgi üzerinde 0 'dan 10'a kadar yerleştirilen rakamların ne anlama geldiği anlatıldı. Hiç ağrı olmamasının 0, karşılaşılan en şiddetli ağrının 10 ve orta derecedeki ağrının da 5'e uyduğu anlatılarak hastaların buna göre ağr1 şiddetlerini tanımlamaları istendi.

\section{İstatistiksel analiz}

Verilerin istatistiksel analiz SPSS (Statistical Package for The Social Sciences, Chicago, Illinois, USA) 18.0 kullanılarak yapıldı. Parametrik değişkenlerin dağılımı Kolmogorov-Smirnov testi kullanılarak değerlendirildi. Bağımsız değişkenlerin kıyaslanmasında veriler normal dağılım göstermişse Student's $t$ testi kullanıldı. Normal dağılım göstermeyen veriler için Mann-Whitney $U$ testi 
kullanıldı. Korelasyon analiz için Pearson testi kullanıldı. P değeri 0.05 altında olanlar istatistiksel olarak anlamlı olarak değerlendirildi.

\section{BULGULAR}

Çalışma; 130 postmenapozal hasta ve 50 sağlıklı kontrol olmak üzere toplam 180 gönüllüden oluşturuldu. Hastaların yaş ortalaması $51.03 \pm 4.22$ yıl ve kontrol grubunun ise 48.37士 5.47'd1. Postmenapozal hasta grubu ile sağlıklı kontrol grubunun laboratuar parametreleri Tablo 1'de gösterilmiştir. Serum 25(OH)D düzeyi hasta grubunda kontrol grubuna göre anlamlı olarak düşük saptand $1(16.98 \pm 11.86-31.47 \pm 12.55 ; \mathrm{p}<0.01)$.

Postmenapozal grupta serum FSH düzeyi kontrol grubuna göre anlamlı olarak yüksek saptanırken $(\mathrm{p}<0.01)$, E2 düzeyi anlamlı olarak düşük bulundu $(\mathrm{p}<0.001)$. Kalsiyum, fosfor, ALP ve PTH düzeyleri arasında her iki grup arasında farklılik görülmedi. A ğr1 durumunu değerlendirmek için kullanılan VAS ağr1 skoru hasta grubunda kontrol grubuna göre anlamlı olarak yüksek saptandı $(\mathrm{p}<0.001)$ (Tablo 1).

Tablo 1: Postmenapozal hastalar ve kontrol grubunda demografik verileri

\begin{tabular}{|l|c|c|}
\hline Parametre & Kontrol Grubu (n=50) & Postmenapozal hastalar (n=130) \\
\hline Yaş (y1l) & $48.37 \pm 5.47$ & $51.03 \pm 4.22$ \\
\hline D vitamini (ng/ml) & $31.47 \pm 12.55$ & $16.98 \pm 11.86$ \\
\hline Glukoz (mg/dL) & $104.22 \pm 16.43$ & $11.22 \pm 21.43$ \\
\hline Total Kolesterol (mg/dL) & $216,27 \pm 41.17$ & $225,27 \pm 39.17$ \\
\hline Trigliserid (mg/dL) & $113.95 \pm 76.1$ & $136.14 \pm 62.49$ \\
\hline HDL Kolesterol (mg/dL) & $55.49 \pm 15.75$ & $51.72 \pm 18.3$ \\
\hline LDL Kolesterol (mg/dL) & $140.55 \pm 31.07$ & $155.86 \pm 42.64$ \\
\hline Kalsiyum (mg/dL) & $9.2 \pm 1.32$ & $9.4 \pm 0.82$ \\
\hline Fosfor (mg/dL) & $4.13 \pm 1.04$ & $3.65 \pm 1.45$ \\
\hline Alkalen Fosfataz (U/L) & $75.83 \pm 17.48$ & $51.97 \pm 25.48$ \\
\hline PTH (pg/ml) & $53.01 \pm 28.47$ & $54.94 \pm 33.98$ \\
\hline FSH (mIU/ml) & $2.22 \pm 1.91$ & $0.115 \pm 0.411$ \\
\hline Östrodiol(E2) (pg/ml) & $37.23 \pm$ & $5.22(2-9)$ \\
\hline VAS Skoru & $1.8(0-8)$ & Horman, HDL: Yüksek Dansiteli \\
\hline ** p<0.05, **p<0.001 VAS: Vizuel Analog Skala, PTH:parathormon, FSH:Follikül Stimülan Hor & \\
Lipoprotein, LDL: Düşü Dansiteli Lipoprotein & & \\
\hline
\end{tabular}

Hasta grubu VAS ağr1 skoruna göre; ağrisı olmayan grup ( $\mathrm{n}=54)$, hafif ağrisı olan grup $(n=35)$, 1 liml ağris1 olan grup $(n=27)$ ve şiddetli ağris1 olan grup $(n=14)$ olmak üzere dört gruba ayrildı. Serum 25(OH)D düzeyleri ağır, 1lımlı ve şiddetli ağrısı olan gruplarda ağrısı olmayan gruba göre anlamlı olarak düşük bulundu $(\mathrm{p}<0.05, \mathrm{p}<0.05, \mathrm{p}<0.01)$. Aynı zamanda şiddetli ağrisı olan grupta serum $25(\mathrm{OH}) \mathrm{D}$ düzeyleri hafif ağrisı olan gruba göre anlamlı olarak düşük saptandı $(\mathrm{p}<0.05)$ (Tablo 2).

Tablo 2: Hasta grubunda VAS'a göre ağr1 şiddetinin değişimine göre $\mathrm{D}$ vitamini düzeylerinin değişimi

\begin{tabular}{|l|c|c|c|c|}
\hline & Ăgr1 yok & Hafif Ă̆r1 & Orta A Ărr1 & Şiddetli Ăgr1 \\
\hline 25 OH D3 & $38.45 \pm 10.16$ & $22.96 \pm 13.92 \mathrm{a}^{*}$ & $19.48 \pm 12.48 \mathrm{~b}^{*}$ & $15.75 \pm 7.96 \mathrm{c}^{* *}, \mathrm{~d}^{*}$ \\
\hline
\end{tabular}

a: Ağr1 olmayan grup ile Hafif ağrısı olan grup arasında, b: Ağrı olmayan grup ile Orta ağrısı olan grup arasında, c: Ağr1 olmayan grup ile Şiddetli ağrısı olan grup arasında, d: Hafif ağrısı olan grup ile Şiddetli ağrısı olan grup arasında. 25(OH)D:25-hydroksi-D vitamini ** $\mathrm{p}<0.05,{ }^{*} \mathrm{p}<0.001$

Tablo 3. Hasta grubunda D vitamini düzeylerinin değişimine göre VAS ağrı skorlarının değerlendirilmesi

\begin{tabular}{|l|c|c|c|}
\hline & $\begin{array}{c}\text { D vitamini Normal olan } \\
\text { grup }(\mathbf{n}=\mathbf{3 4})\end{array}$ & $\begin{array}{c}\text { D Vitamini Yetersizliği olan } \\
\text { grup (21-29) }(\mathbf{n}=46)\end{array}$ & $\begin{array}{c}\text { D Vitamini Eksikliği olan } \\
\text { grup }(<21)(\mathbf{n}=50)\end{array}$ \\
\hline VAS & $1.16(0-6)$ & $4.0(0-9) \mathrm{a}^{*}$ & $4.71(2-9) \mathrm{b}^{* *}$ \\
\hline
\end{tabular}

a: D vitamini Normal olan grup ile Yetersizliği olan grup arasında, b: D vitamini Normal olan grup ile Eksikliği olan grup arasında VAS: Vizuel Analog Skala; ${ }^{*} \mathrm{p}<0.01,{ }^{* *} \mathrm{p}<0.001$

Hastaların \%39’unda D vitamini eksikliği, \%35’inde ise D vitamini yetersizliği olup, sadece \%26'sında D vitamini düzeyleri yeterli idi. $\mathrm{D}$ vitamini eksikliği ve yetersizliği olan postmenapozal hastalarda VAS ağr1 
skorlar1 D vitamini düzeyleri yeterli olan gruba göre anlamlı olarak yüksek saptand $(\mathrm{p}<0.05, \mathrm{p}<0.01)$ (Tablo 3). Hastalar tarif edilen ağrı bölgesine göre; ağrıs1 olmayanlar, alt ekstremite ağrısı olanlar ve üst ekstremite ağrısı olanlar olarak üç gruba ayrıldı. Serum 25(OH)D düzeyleri alt ve üst ekstremite ağrısı olan grupta ağrısı olmayan gruba göre anlamlı olarak düşük saptandı (her ikiside $\mathrm{p}<0.01$ ). Alt ekstremite ağrıs1 olan grupta ise serum 25(OH)D düzeyleri üst ekstremite ağrısı olan gruba göre anlamlı olarak düşük $(\mathrm{p}<0.05)$ ve VAS ağrı skoru anlamlı olarak yüksek bulundu $(\mathrm{p}<0.05)$ (Tablo 4).

Tablo 4: Hasta grubunda tarif edilen ağrı bölgesine göre D vitamini düzeyleri ve VAS skorlarının değişimi

\begin{tabular}{|l|c|c|c|}
\hline & Ăgrıs1 Olmayan Grup (n=54) & Alt Ekstremite Ağris1 (n=34) & Üst Ekstremite Ağris1 (n=42) \\
\hline 25 OH D3 & $38.45 \pm 10,17$ & $16.91 \pm 14.27 \mathrm{a}^{* *}$ & $21.99 \pm 10.54 \mathrm{~b}^{* *}, \mathrm{c}^{*}$ \\
\hline VAS & - & $5.34 \pm 2.42$ & $4.03 \pm 2.64 \mathrm{c}^{*}$ \\
\hline
\end{tabular}

a: Ağr1 olmayan grup ile Alt ekstremite ağrisı olan grup arasında, b: Ağr1 olmayan grup ile Üst ekstremite ağrisı olan grup arasında, c: Alt ekstremite ağrısı ile Üst ekstremite ağrısı olan grup arasında VAS: Vizuel Analog Skala, 25(OH)D:25-hydroksi-D vitamini

$* * p<0.05, * * p<0.001$

Hasta grubunda uygulanan korelasyon analizinde $25(\mathrm{OH}) \mathrm{D}$ düzeyleri ile yaş, VKİ ve VAS skoru arasinda negatif bir korelasyon ve $25(\mathrm{OH}) \mathrm{D}$ düzeyleri ile egzersiz ve E2 arasinda pozitif korelasyon saptandı (sirasiyla: $\mathrm{r}=-0.429-\mathrm{p}=0.008$; $\mathrm{r}=-0.408-\mathrm{p}=0.012 ; \mathrm{r}=-0.243-\mathrm{p}=0.044 ; \mathrm{r}=0.433-$ $\mathrm{p}=0.007 ; \mathrm{r}=0.367-\mathrm{p}=0.026)$.

\section{TARTIŞMA}

Kadınlarda yaş ilerledikçe ovarian folüküllerin sayısındaki azalmaya bağlı olarak dolaşımdaki östrojen miktarı azalmakta ve menapozal semptomların açığa çıkmasına sebep olmaktadır ${ }^{18}$. Yaşlanmayla birlikte östrojenin azalmasıyla ilgili olarak kemik kayıpları da görülmektedir ${ }^{19}$. Bu semptomlardan en önemlisi osteoporozdur. Östrojen eksikliğine bağlı olarak yaşla birlikte kas, iskelet ve eklem ağrılarında belirgin şekilde artı̆̆ bilinmektedir.

Son yıllarda D vitamininin kemik ve mineral metabolizması üzerine olan etkileri ile ağn1 mekanizmalarında rol oynayabileceği bildirilmiştir ${ }^{20}$. Vitamin D'nin kalsiyum hemostazındaki öneminin yanı sıra, kemik ve kas sağlı̆̆ının sürdürülebilmesi içinde hayati önemi vardır ${ }^{13}$. D vitamini eksikliği kollagen matriksin mineralizasyonu için gerekli olan kalsiyum fosfatın eksikliğine yol açar. Bunun sonucu olarak matriksin periostumun altına doğru genişleyerek diffuz ağrıyı tetiklediği bildirilmiştir ${ }^{16}$.

Çalışmamızda hasta grubu oluşturulurken osteoporoz tanis1 almayan postmenapoz hastaları seçildi ve ağrı ile ilişkili klinik durumlar dışlandı. Kas iskelet ağrisı bulunan postmenapozal hastalarda serum $25(\mathrm{OH}) \mathrm{D}$ düzeyi kontrol grubuna göre anlamlı olarak düşük saptandı $(\mathrm{p}<0.01)$. Aynı zamanda hastaların ağrı durumunu değerlendirmek için kullanılan VAS ağr1 skoru postmenapozal hastalarda kontrol grubuna göre anlamlı olarak yüksek saptandı $(\mathrm{p}<0.001)($ Tablo 1$)$. Bu sonuçlar da $\mathrm{D}$ vitamini düşüklüğü ile ağr1 arasında bir ilişkinin varlığını düşündürmektedir. Bu bulguyu destekler şekilde VAS ağr1 skoruna göre hasta grubu değerlendirildiğinde serum $25(\mathrm{OH}) \mathrm{D}$ düzeyleri ağır, 1lımlı ve şiddetli ağrısı olan gruplarda ağrısı olmayan gruba göre anlamlı olarak düşük bulundu $(\mathrm{p}<0.05$, $\mathrm{p}<0.05, \mathrm{p}<0.01)$. Aynı zamanda şiddetli ağrısı olan grupta serum $25(\mathrm{OH}) \mathrm{D}$ düzeyleri hafif ağrisı olan gruba göre anlamlı olarak düşük saptandı $(\mathrm{p}<0.05)$ (Tablo 2). Ağr1 şiddetindeki artışın, 25(OH)D düzeylerindeki azalmayla ilişkili olduğunu göstermektedir. Ancak sonuçların aksini iddia eden çalışmalarda vardır. Warner ve arkadaşları ${ }^{21}$ yaptığı çalışmada $25(\mathrm{OH}) \mathrm{D}$ vitamin düşüklüğü ile yaygın kas iskelet sistemi ağrısı arasında ilişki bulmamışlardır. Çalışmamızda hastaların \%39’unda $\mathrm{D}$ vitamini eksikliği, \%35'inde ise $\mathrm{D}$ vitamini yetersizliği olup, sadece \%26'sinda D vitamini düzeyleri yeterli idi. D vitamini eksikliği ve yetersizliği olan postmenapozal hastalarda VAS ağr1 skorlar1 D vitamini düzeyleri yeterli olan gruba göre anlamlı olarak yüksek saptandı $(\mathrm{p}<0.05, \mathrm{p}<0.01)$ (Tablo 3). Bu sonucumuzu destekler şekilde Didem ve $\operatorname{arkadaşlar1}^{22} \mathrm{D}$ vitamini seviyeleri düşük olan grupta kas iskelet sistemine ait ağrıların, D vitamini tedavi öncesi ve sonrasına göre kıyaslandığında D vitamin seviyeleri ve VAS arasinda ters orantı bulmuşlardır. Yine aynı çalışmada vitamin D ile ağnı yoğunluğu arasındaki ilişki incelenmiş olup $25(\mathrm{OH}) \mathrm{D}$ düzeyleri ile ağrı VAS arasında anlamlı fark bulunamamıştır. Ancak bu bulguların aksini bildiren çalışma sonuçları da bildirilmiştir. Benzer şekilde Mahmut ve arkadaşları ${ }^{23}$ yaptı̆̆ kas iskelet sistem ağrısı ve $\mathrm{D}$ vitamini düzeyleri 
arasında yaptığ1 çalışmada; düşük ve normal serum $25(\mathrm{OH}) \mathrm{D}$ seviyelerine göre ağrinın VAS ile değerlendirmesinde anlamlı fark bulmamıştır. Bu çelişkili sonuçların nedenleri D vitamini ile ağr1 arasındaki mekanizmaların kompleks olmasi ve seçilen hasta gruplarının klinik özelliklerindeki farklılıklardan kaynaklanabilir.

Çalışmamızda hastalar tarif edilen ağrı bölgesine göre değerlendirildiğinde serum $25(\mathrm{OH}) \mathrm{D}$ düzeyleri ekstremite ağrısı olan grupta, ağrısı olmayan gruba göre anlamlı olarak düşük saptandı. Bölgesel olarak k1yaslandığında alt ekstremite ağrisı olan grupta serum $25(\mathrm{OH}) \mathrm{D}$ düzeyleri üst ekstremite ağrısı olan gruba göre anlamlı olarak düşük bulundu $(\mathrm{p}<0.05)$ (Tablo 4). Bulgularımızı destekler şekilde Heidari ve arkadaşlari $^{24} 25(\mathrm{OH}) \mathrm{D}$ düzeylerini alt ekstremite ağrısı olan hastalarda, üst esktremite ağrisı olan

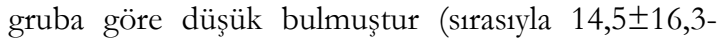
$33,9 \pm 32,9)$. Bizim sonuçlarımızla birlikte değerlendirildiğinde $25(\mathrm{OH}) \mathrm{D}$ düzeylerindeki düşüşün alt ekstremite ağriları ile daha ilişkili olduğunu göstermektedir. Bu bulgularımızın aksine Hicks ve $\operatorname{arkadaşlar1}^{25} \mathrm{D}$ vitamin düzeyi $25 \mathrm{nmol} / \mathrm{L}$ 'nin altında olan kadın hastalarda üst ekstremite ağrıları görülen hastaların alt ekstremite ağriları olanlara göre daha fazla görüldüğünü bildirmiştir (sırasıyla \%17,\%9). Ancak D vitamin düzeyleri $25 \mathrm{nmol} / \mathrm{L}$ üstü olan grupta alt ve üst ekstremite ağrılarının görülme sıklığ1 arasında fark bulamamıştır. Genellikle 25(OH)D düzeylerinin ağr1 ile ilişkisini inceleyen çalışmalar sırt üst ekstremite ağrısına odaklanmıştır. Yine aynı çalışmada yalnızca $25(\mathrm{OH}) \mathrm{D}$ düzeylerinin $25 \mathrm{nmol} / \mathrm{L}$ altındaki hastaların yüzdesini içermesi bu konuda net bilgi vermemektedir. Silva ve $\operatorname{arkadaşlar1}^{26}$ yaptığ çalışmada bölgesel ağrı ile D vitamini düşüklüğü arasında istatistiksel olarak anlamlı fark olduğu bulunmuş ve $\mathrm{D}$ vitamin düşüklüğü bulunan postmenapozal kadınlarda lumbasakral bölgede diğer bölgelere kıyasla daha fazla ağriya sahip olduklarını göstermişlerdir.

Hasta grubunda 25(OH)D düzeyleri ile ilişkili faktörler arasındaki ilişkiler araştırıldı̆̆ında $25(\mathrm{OH}) \mathrm{D}$ düzeyleri ile VAS ağrı skoru arasında negatif korelasyon saptandı (Tablo 5). Bu sonuçlara benzer şekilde Al-Eisa ve arkadaşları ${ }^{27}$ sağlıklı yaşlılar üzerine yaptığı çalışmada serum $25(\mathrm{OH}) \mathrm{D}$ konsantrasyonu ile VAS skoru arasında negatif korelasyon bulmuştur. İki çalışma birlikte değerlendirildiğinde $25(\mathrm{OH}) \mathrm{D}$ düzeyleri ile ağr1 arasındaki ilişkiyi net bir şekilde ortaya koymaktadır.
İlginç şekilde $25(\mathrm{OH}) \mathrm{D}$ düzeyleri ile VKİ arasında negatif korelasyon varlığ1 bir çok çalışmada gösterilmiştir ${ }^{27,28,29}$. Mattam ve arkadaşları ${ }^{29}$ bunun sebebini D vitamininin adipöz dokuda depolanmasına bağlamışlar ve sonuç olarak yüksek VKI'ne sahip olan bireylerde lumbo sakral ağr1 insidansını daha yüksek tespit etmişlerdir. Bettencourt ve arkadaşları ${ }^{30}$ yaptı̆̆ çalışmada sağlıklı obez ve nonobez bireyler arasinda 25(OH)D'nin VKİ ile kiyaslamasında negatif korelasyon bulmuşlardır. Yine aynı çalışmada Obezite ile vitamin D'nin negatif ilişkisini $\mathrm{D}$ vitaminin vücut yağ bölmelerinde tutulumundan dolayı, deri ve beslenme kaynaklı $\mathrm{D}$ vitamininin biyoyararlanımının azalmasından dolayı olduğu ifade etmişlerdir. Bu bilgeler 1şığında 25(OH)D düzeylerinin ağr1 mekanizmalarındaki rolü VKİ'nin oranıla ters orantılı olarak değişebileceğini göstermektedir.

Östrojen düzeyi ile D vitamini arasındaki ilişki oldukça dikkat çekicidir. E2'nin böbreklerde 1,25$(0 \mathrm{H}) 2 \mathrm{D} 3$ sentezini $^{31}$ ve duodenal mukozada ${ }^{32}$, osteoklastlarda vitamin D reseptörü (VDR) ekspresyonların133 ${ }^{33}$ uyardığı gösterilmiştir. Böylece intestinal kalsiyum transportu ${ }^{32,34}$ ve ALP aktivitesini arttırmaktadır ${ }^{35}$. Çalışmamızda 25(OH)D düzeyleri ile E2 arasında pozitif korelasyon varlığ1 postmenapozal dönemde E2 ve D vitamini düşüklüğünün, ağrının ortaya çıkmasında birlikte etkili olduğunu düşündürmektedir. Ancak ağr1 mekanizmalarının kompleks olması nedeniyle bu ilişkinin rolü daha geniş çalışmalarla desteklenmelidir.

Çalışmamızda hasta sayısının azlığı, kısıtlllığ1 olarak değerlendirilebilir. Ancak özellikle alt ve üst ekstremite ağrılarının değerlendirilmesinde D vitamini düzeylerini inceleyen az sayıdaki çalışmadan biri olması oldukça önemlidir.

Sonuç olarak; Postmenapozal KİSA önemli yaşam kalitesi sorunudur. Serum $25(\mathrm{OH}) \mathrm{D}$ düzeyi hasta grubunda kontrol grubuna göre anlamlı olarak düşük saptand. Ağrı durumunu değerlendirmek için kullanılan VAS ağr1 skoru hasta grubunda kontrol grubuna göre anlamlı olarak yüksek saptandi. Postmenapozal hastalarda VAS ağr1 skorları D vitamini eksikliği ve yetersizliği olan gruplarda, D vitamini düzeyleri yeterli olan gruba göre anlamlı olarak yüksek saptand1. Hasta grubunda $25(\mathrm{OH}) \mathrm{D}$ düzeyleri ile VAS skoru arasinda pozitif korelasyon saptandı. Postmenapozal hastalarda ağrı şiddetindeki artışın 25(OH)D düzeylerindeki azalmayla ilişkili olduğunu göstermektedir. Üstelik 25(OH)D 
düzeyleri düșük hastalarda alt ekstremite ağrılarının daha fazla görüldügü ve $25(\mathrm{OH}) \mathrm{D}$ 'nin KISA şiddetini belirlemede rol oynayabileceği kanısındayız. $\mathrm{Bu}$ nedenle hastaneye başvuran her hastanın laboratuar isteminde yer alan D vitamini değerlerinin bu amaçla incelenmesinin faydalı olacağını düşünmekteyiz. Özellikle D vitamini düzeyleri düşük hastalarda alt ekstremite ağrılarının daha fazla görülmesi oldukça önemli bir bulgudur ve KİSA şiddetini belirlemedeki prognostik rolünün hastanın tedavi edilmesinde kullanılabileceği kanısındayız. Ancak D vitamini düzeyleri ve postmenapozal kadınlarda görülen KISA arasındaki ilişkiyi desteklemek için daha fazla kanıta ihtiyaç vardır.

\section{KAYNAKLAR}

1. WHO Scientific Group on the Burden of Musculoskeletal Conditions at the Start of the New Millennium. The burden of musculoskeletal conditions at the start of the new millennium. World Health Organ Tech Rep Ser. 2003;919:1-218.

2. Woolf AD, Pfleger B. Burden of major musculoskeletal conditions. Bull World Health Organ. 2003;81:646-56.

3. Kadi F, Karlsson C, Larsson B, Eriksson J, Larval M, Billig $\mathrm{H}$ et al. The effects of physical activity and estrogen treatment on rat fast and slow skeletal muscles following ovariectomy. J Muscle Res Cell Motil. 2002;23:335-9.

4. Greising SM, Baltgalvis KA, Lowe DA, Warren GL. Hormone therapy and skeletal muscle strength: a meta-analysis. J Gerontol A Biol Sci Med Sci. 2009;64:1071-81.

5. Nedergaard A, Henriksen K, Karsdal MA, Christiansen C. Menoupause, estrogens and frailty. Gynecol Endocrinol. 2013;29:418-23.

6. Dennerstein L, Dudley EC, Hopper JL, Gurthrie JR, Burger HG. A prospective population-based study of menopausal symptoms. Obstet Gynecol. 2000; 96: 351-8.

7. Bischoff-Ferrari HA, Willett WC, Wong JB, Giovannucci E, Dietrich T, Dawson-Hughes B. Fracture prevention with vitamin D supplementation: a meta-analysis of randomized controlled trials. JAMA. 2005;293:2257-64.

8. Bischoff-Ferrari HA, Dietrich T, Orav EJ, Hu FB, Zhang Y, Karlson EW et al. Higher 25hydroxyvitamin D concentrations are associated with better lower-extremity function in both active and inactive persons aged $>$ or $=60 \mathrm{y}$. Am J Clin Nutr. 2004;80:752-8.

9. $\mathrm{Al}$ Faraj S, Al Mutairi K. Vitamin D deficiency and chronic low back pain in Saudi Arabia. Spine. 2003;28:177-9.
10. Gloth FM 3rd, Lindsay JM, Zelesnick LB, Greenough WB 3rd. Can vitamin D deficiency produce an unusual pain syndrome? Arch Intern Med. 1991;15:1662-4.

11. Mascarenhas R, Mobarhan S. Hypovitaminosis Dinduced pain. Nutr Rev. 2004;62:354-9.

12. Plotnikoff GA, Quigley JM. Prevalence of severe hypovitaminosis D in patients with persistent, nonspecific musculoskeletal pain. Mayo Clin Proc. 2003;78:1463-70.

13. Gerdhem P, Ringsberg KA, Obrant KJ, Akesson K. Association between 25-hydroxy vitamin D levels, physical activity, muscle strength and fractures in the prospective population-based OPRA Study of Elderly Women. Osteoporos Int. 2005;16:1425-31.

14. Lips P, Hosking D, Lippuner K, Norquist JM, Wehren L, Maalouf $G$ et al. The prevalence of vitamin $\mathrm{D}$ inadequacy amongst women with osteoporosis. an international epidemiological investigation. J Intern Med. 2006;260:245-54.

15. Heaht IKM, Elovic EP. Vitamin D deficiency: implications in the rehabilitation setting. Am J Phys Med Rehabil. 2006;85:916-23.

16. Holick MF. Vitamin D deficiency: what a pain it is. Mayo Clin Proc. 2003;78:1457-9.

17. Holick MF. Vitamin D deficiency. N Engl J Med. 2007;357:266-81.

18. Kronenberg F. Hot Flashes: Epidemiology and Physiology. Ann N Y Acad Sci. 1990;592:52-86.

19. Beyene Y, Martin MC. Menopausal experiences and bone density of Mayan women in Yucatan, Mexico. Am J Hum Biol. 2001;13:505-11.

20. Hicks GE, Shardell M, Miller RR, Bandinelli S, Guralnik J, Cherubini A et al. Associations between vitamin $\mathrm{D}$ status and pain in older adults: the Invecchiare in Chianti study. J Am Geriatr Soc. 2008;56:785-91.

21. Warner AE, Arnspiger SA. Diffuse musculoskeletal pain is not associated with low vitamin D levels or improved by treatment with vitamin D. J Clin Rheumatol. 2008;14:12-6.

22. Özcan DS, Öken Ö, Aras M, Köseoğlu BF. Fibromiyaljili kadın hastalarda vitamin $\mathrm{D}$ düzeyleri ve ağrı, depresyon, uyku ile ilişkisi. Türk Fiz Tıp Rehab Derg. 2014;60:329-34.

23. Yener M. Kas iskelet sistem ağrisı ile vitamin D düzeyleri arasındaki ilişkinin araştırılması. S.D.Ü. Tıp Fak. Derg. 2007;14:7-11.

24. Heidari B, Shirvani JS, Firouzjahi A, Heidari P, Hajian-Tilaki KO. Association between nonspecific skeletal pain and vitamin D deficiency. Int J Rheum Dis. 2010;13:340-6.

25. Hicks GE, Shardell M, Miller RR, Bandinelli S, Guralnik J, Cherubini A. Associations between vitamin $\mathrm{D}$ status and pain in older adults: the Invecchiare in Chianti study. J Am Geriatr Soc. 2008;56:785-91. 
26. e Silva AV, Lacativa PG, Russo LA, de Gregório LH, Pinheiro RA, Marinheiro LP. Association of back pain with hypovitaminosis $\mathrm{D}$ in postmenopausal women with low bone mass. BMC Musculoskelet Disord. 2013;14:184.

27. Al-Eisa ES, Alghadir AH, Gabr SA. Correlation between vitamin $\mathrm{D}$ levels and muscle fatigue risk factors based on physical activity in healthy older adults. Clin Interv Aging. 2016;11:513-22.

28. Lumachi F, Camozzi V, Doretto P, Tozzoli R, Basso SM. Circulating PTH, Vitamin D and IGF-I levels in relation to bone mineral density in elderly women. In Vivo. 2013;27:415-8.

29. Mattam A, Sunny G. Correlation of vitamin D and body mass index with modic changes in patients with non-specific low back pain in a sub-tropical Asian population. Asian Spine J. 2016;10:14-9.

30. Bettencourt A, Boleixa D, Reis J, Oliveira JC, Mendonça D, Costa PP et al. Serum 25hydroxyvitamin D levels in a healthy population from the North of Portugal. J Steroid Biochem Mol Biol. 2016;pii:S0960-0760(16)30298-9.
31. Heikkinen A, Parviainen MT, Tuppurainen MT, Niskanen L, Komulainen MH, Saarikoski S. Effects of postmenopausal hormone replacement therapy with and without vitamin D3 on circulating levels of 25-hydroxyvitamin D and 1,25-dihydroxyvitamin D. Calcif Tissue Int. 1998;62:26-30.

32. Nordin BEC, Need AG1 Morris HA, Horowitz M. Biochemical variables in pre- and postmenopausal women: reconciling the calcium and estrogen hypotheses. Osteoporosis Int. 1999;9:351-7.

33. Eriksen EF, Langdahl B, Vesterby A, Rungby J, Kassem M. Hormone replacement therapy prevents osteoclastic hyperactivity: A histomorphometric study in early postmenopausal women. J Bone Miner Res. 1999;14:1217-21.

34. Criddle RA, Zheng MH, Dick IM, Callus B, Prince RL. Estrogen responsiveness of renal calbindinD28K gene expression in rat kidney. J Cel1 Biochem. 1997;65:340-8.

35. Schmidt IU, Wakley GK, Turner RT. Effects of estrogen and progesterone on tibia histomorphometry in growing rats. Calcif Tissue Int. 2000;67:47-52. 